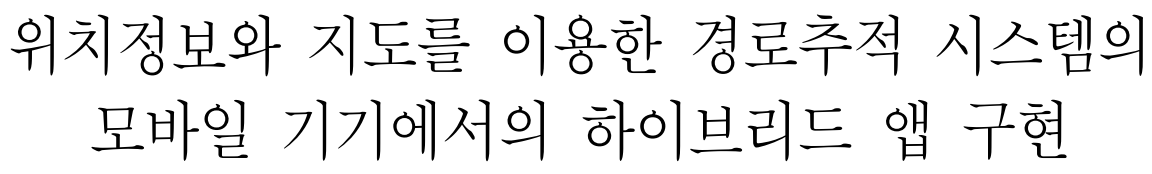

\title{
Implementation of a Hybrid-App of a Path Tracking System Using Geolocation and Maps on Mobile Devices
}

\author{
유문성 * \\ Moon-Sung Yoo* \\ 요 약
}

위치정보와 지도를 이용하여 자신이나 타인 또는 사물의 경로추적이 필요한 경우가 있다. 최근에 모바일 기기의 발달은 이것을 가능하게 하였다. 지금까지 스마트폰이나 태블릿 컴퓨터등의 모바일기기의 경로추적 시 스템을 개발하는데 네이티브 방법을 사용하였다. 이 방법의 단점은 같은 서비스를 다른 플랫폼에 제공하려면 다시 작업해야한다는 것이다. 이런 단점을 극복하기 위하여 웹 앱과 하이브리드 앱이 개발되었다. 하이브리 앱 은 네이티브앱과 외관상 비슷하기 때문에 사용자들이 웹 앱보다 더 선호한다. 본 논문에서는 모바일 기기에서 경로탐색이 가능한 앱을 개발하였다. 최근에 나온 HTML5에 위치정보 기능이 추가 되었는데 이를 이용하여 경 로추적 시스템을 하이브리드 앱으로 구현하였다. 먼저 HTML5, CSS 와 자바스크립트 등을 이용하여 웹 앱을 만들고 이를 하이브리드 앱 도구의 하나인 폰갭을 이용하여 하이브리드 앱으로 변환하였다. 이 시스템의 구현 으로 경로탐색이 필요한 여러 분야에서 모바일 기기에 관계없이 빠르고 효율적인 앱 개발이 가능하게 되었다.

\section{Abstract}

By using geolocation and maps, we need to trace the path of ourselves, others, or the objects. Until now, we used a native apps development mehod to develop path tracking systems in mobile devices such as smart phones and tablet computers. A disadvantage of this method is that we have to work again to provide the same service on different platforms. Web Apps and Hybrid Apps are developed to recover this disadvantage. Since Hybrid Apps look like Native Apps apparently, users prefer Hybrid Apps to Web Apps. In this paper, we develop a hybrid app which can trace the path on mobile devices. The recently suggested next generation markup language, HTML5, has geolocation features. By using them, we implemented a hybrid app for a path tracking system. First, we create a web app using HTML5, CSS, and JavaScript, Then, PhoneGap, a mobile development framework, is used to convert it to the hybrid app. By implementing hybrid app, various apps which need path tracking can be developed rapidly and effectively, regardless of the mobile devices.

Key words : Path Tracking, Geolocation, Mobile Apps, Hybrid Apps, Web Apps, HTML5

* 상지대학교 컴퓨터정보공학부(Dept. of Computer Information Engineering, Sangji University)

· 제1저자 (First Author) : 유문성(Moon-Sung Yoo, tel : +82-10-8410-3698, email : msyoo@sangji.ac.kr )

· 접수일자 : 2013년 11월 24일 · 심사(수정)일자 : 2013년 11월 24일 (수정일자 : 2013년 12월 26일) · 게재일자 : 2013년 12월 30일 http://dx.doi.org/10.12673/jkoni.2013.17.6.633 
되고 있는 스마트폰과 LBS (Location Based Service) 기술을 이용하여 자신이나 타인의 위치 정보 를 지도상에서 알아야 할 필요가 많이 있다. 예를 들 어, 차를 운전하거나, 길을 찾을 때, 또는 어린 자녀 가 집 밖에 있을 때 수시로 자녀의 위치를 확인하기 를 원한다.

예전에는 이런 위치정보에 관한 것을 얻기가 거의 불가능하였는데 스마트폰 등 모바일 기기가 대중화 되어 자신이나 타인의 위치정보를 언제, 어디서나 얻 는 것이 가능하게 되었다.

어느 한 순간의 위치 정보가 필요한 경우도 있지 만 연속적으로 위치정보를 추척할 필요도 있다. 이 때 그 위치들의 정보를 모니터링한 것이 경로추적 시스템이다.

지금까지는 스마트폰이나 스마트 패드등 위치 정 보 획득이 가능한 모바일 기기에서 위치정보를 이용 한 앱을 개발하려면 기기에 맞는 네이티브 언어 즉 Objective-C 또는 Java와 같은 언어를 사용하여 개발 하는 네이티브 웹 개발 방법을 사용하였다. 이 방법 은 서로 다른 플랫폼에 동일한 앱을 서비스하기 위해 서는 다른 언어로 개발해야 하는 불편함이 있었다.

최근에 $\mathrm{W} 3 \mathrm{C}$ 에서 차세대 웹을 위한 새로운 HTML 언어인 HTML5를 제안하였으며 현재 표준화 작업이 진행 중인데 HTML5에서는 위치정보(지오 로케이션) 의 사용과 지도(맵)의 출력이 플러그인 없이 가능하 다. 또한 하이브리드 앱 도구의 등장으로 모바일기기 의 플랫폼에 관계없는 앱의 개발이 가능하게 되었다.

본 논문은 HTML5에 새로이 추가된 위치정보 기 능을 이용하여 경로추적 시스템을 하이브리드 앱으 로 구현하였다. 먼저 HTML5, CSS, Javascript 등을 이용하여 웹 앱을 만들고 이를 하이브리드 앱 도구 의 하나인 PhoneGap(폰갭)을 이용하여 하이브리드 앱으로 변환하였다.

\section{II. 관련 연구}

2-1 LBS 기술 개요[1,2]

2-1-1 무선측위기술
LBS는 무선 및 유선 통신을 통해 이동 중인 사용 자에게 신속하고 편리하게 사용자의 위치와 관련된 다양한 정보를 제공하는 서비스를 말한다. 이 중 이 동 중에도 이용할 수 있는 것이 무선측위기술인데 이 기술에는 위성기반 측위기술과, 네트워크 기반 측위 기술, 혼합 측위 기술, 유비쿼터스 측위기술이 있다.

위성기반 측위기술(GPS)은 미 국방성에서 운영 하고 있는 위성 기반 항법 장치이며 지구 궤도상에 배치된 24 개의 인공위성과 지상에서 인공위성을 통 제하는 관제국 그리고, 사용자의 GPS 수신기로 구성 되어 있으며 정확도가 높으나 빌딩이 많은 도심지역, 나무가 많은 삼림지역이나 실내에서 위치를 결정하 지 못하는 문제가 있다.

네트워크 기반 측위기술(이동통신망 기술)은 $\mathrm{CDMA}, \mathrm{GSM}, \mathrm{WCDMA}$ 등과 같은 이동통신망 시스 템을 이용하여 위치 측위를 수행하며, 기지국과 위치 인식 관련 서버들 그리고 이동 단말기로 구성되어 있 다. 위치 정확도가 통신망의 기지국 cell 크기와 측정 방식에 따라 차이가 많다.

혼합 측위기술은 GPS와 네트워크 기반 측위기 술 의 각 단점을 상호 보완하기 위해 개발된 것으로 대표적인 기술로 A-GPS (Assisted GPS)가 있다. A-GPS 는 초기 위치인식 시간을 기존의 GPS 방식보 다 줄일 수 있으며, GPS 신호를 받을 수 없는 지역에 서는 이동통신망 기반 측위 방식인 Cell ID 방식을 따 른다. 이 기술은 사용하기 쉽고 정확도가 높으나 전 력소모량이 많고 워밍업 시간이 오래 걸린다.

유비쿼터스 측위기술에는 RF신호, RFID를 이 용한 위치측위 시스템 등이 있다. RF신호를 이용한 측위시스템은 WLAN의 $\mathrm{AP}$ 로부터 수신되는 RF 신호

의 세기나 RF 신호의 전달 지연을 이용하여 위치 를 파악하는 시스템이다. 설치 비용이 저렴한 장점이 있으나 신호도달 거리가 짧다.

RFID를 이용한 위치측위 시스템은 두 가지 유 형이 있는데 하나는 RFID 리더기를 고정된 위치에 설치하여 RFID태그를 소지한 사용자나 물체가 통과 시 그 위치정보를 활용하는 방식이며 다른 하나는 특 정 위치에 태그를 부착하고 사용자가 리더기를 휴대 하여 사용자의 위치를 알아내는 방법이다. 
2-1-2 LBS 플랫폼 구성요소

LBS 플랫폼은 이동 통신망과 LBS 응용서비스 사 이에서 필요한 기반 기술을 제공하며 위치 포탈 서 버, 위치 데이터 서버, 위치 응용 서버로 구성된다.

위치 포탈 서버는 통신망 접속과 관리, 위치 및 사 용자 정보 서비스, 과금, 로밍 등의 기본 서비스를 위 한 플랫폼 운영기능을 지원한다.

위치 데이터 서버는 이동하는 객체의 위치 정보를 획득, 저장, 검색, 갱신하는 기술로 대용량 메모리 데 이터베이스(MMDB, Main Memory DB)를 지원하기 위한 서버다.

위치 응용 서버는 다양한 애플리케이션을 위한 서버로 지오코딩, 지도 정보, 경로탐색, 위치기반 텔 레매틱스, 위치기반 전자상거래, 실시간 위치정보 기 반 온라인 게임 등을 지원한다.

\section{2-2 HTML5}

최근 다양한 플랫폼을 이용한 모바일 기기들에서 의 웹의 수요가 증가하고 있다. 하지만 기존의 웹에 서 동적인 환경을 구현하기 위해서 사용해야 하는 외 부 플러그인들을 구동하기 위해서는 많은 자원을 필 요로 한다. 더구나, 하드웨어 및 소프트웨어 사양이 다양하면서도 유휴 자원이 적은 모바일 기기들에서 구동하기란 매우 어렵다. 이러한 문제가 대두되면서 $\mathrm{W} 3 \mathrm{C}$ 에서는 차세대 웹 표준 개발으로 WHATWG (Web Hypertext Application Technology Working Group)에서 제안한 HTML5를 승인하고 표준화 작업 을 시작하였다[3].

HTML5은 별도의 플러그인을 설치하지 않고도 멀 티미디어 자원인 동영상, 오디오를 재생 및 제어할 수 있으며, 위치정보, 웹 저장소, 웹 워커 등 다양한 기능을 지원하고 있다[4]. 따라서 플랫폼 독립적인 웹 응용 서비스의 개발이 가능해지고, 기존 로컬 응 용 어플리케이션의 일부를 대체할 수 있게 되었다.

\section{2-3 하이브리드 앱}

모버일 기기의 앱은 크게 네이티브 앱, 웹 앱, 하이브리드 앱으로 나눌 수 있다.
네이티브 앱은 $\mathrm{iOS}$, 안드로이드와 같은 모바일 운 영체제가 제공하는 개발 환경에서 Objective-C 또는 Java와 같은 전용 언어를 사용하여 만들어지는 애플 리케이션을 말한다. 네이티브 애플리케이션은 해당

운영 체제에서만 동작하며 다른 운영체제에서는 동작하지 않는다

웹 앱은 브라우저에서 작동하는 HTML, Javascript, CSS를 이용해 작성된 앱으로서, 원격의 모바 일 웹 서버에서 주된 기능을 수행하기 때문에 플랫 폼 별로 개발할 필요가 없다. 그러나 모바일 기 기의 하드웨어 자원을 사용할 수 없는 단점이 있다.

하이브리드 앱은 웹기술로 개발한 앱을 네이티브 앱에서 제공되는 환경에서 실행되게 변환한 앱이다. 이 방법은 앞에서 소개한 두 종류 방법의 장점을 알 맞게 융합한 것으로 하이브라이드 앱은 UI를 만들 때 웹 기술을 이용하며 여러 기기용 앱을 만드는 경우에 도 기기별로 의존할 수 있는 개발기술이 크게 필요하 지 않게 되어 개발비가 적게 든다.

하이브리드 앱은 먼저 HTML5, Javascript, CSS 등 을 이용하여 웹 앱을 만들고, 폰갭 등 하이브리드 웹용 도구를 이용해 패키징하고, 웹킷 (Webkit)이 제 공되는 브라우저가 탑재된 모바일 기기에 배포되어 웹 컴포넌트 기반으로 실행된다. 그림 1에 3가지 앱 개발 방법에 대해서 나타냈다[5][6].

\section{2-4 위치정보 및 지도}

지도와 사용자의 위치와 지도 정보를 필요로 하는 산업분야와 수요가 날로 증가하고 있다. 위치 정보는 geolocation(지오 로케이션)을 사용하여 얻는데 IP 주소, $\mathrm{GPS}$, 기지국 이용 삼각측량법, 와이파이 이용 삼각측 량법을 통해서 얻어지게 된다. 지도는 구글 맵, 네이 버맵 등을 사용하여 나타낸다.

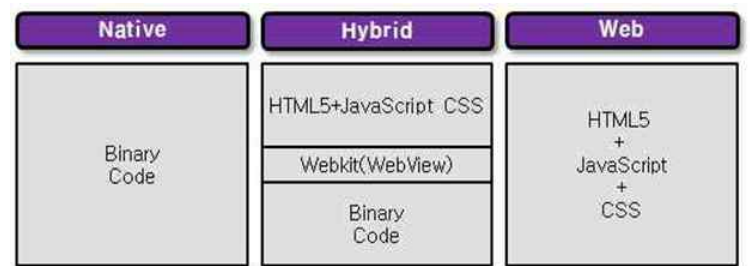

그림 1. 모바일 앱 개발 방법

Fig. 1. Mobile App Development 
기존에는 위치와 지도 정보를 얻기 위해서 Java나 Objective-C 등 네이티브 언어를 사용하여 복잡하게 구현하였는데 차세대 웹인 HTML5의 등장으로 CSS 와 Javascript와 API를 이용하여 손쉽게 작성할 수 있 게 되었다.

\section{III. 시스템 구현}

\section{3-1 시스템 개요}

제안 시스템은 LBS기술을 이용하여 경로 추적이 필요한 자신이나 타인을 추적하기 위한 시스템이다.

전체적인 시스템은 그림 2와 같이 GPS나 기지국 등을 이용 위치추적이 가능한 모바일 기기, 네트워 크, 경로 추적 앱으로 구성되어 있다.

경로 추적 앱은 HTML5, CSS3 와 Javascript를 이용 하여 경로추적 웹앱을 만들고 폰갭을 이용하여 하이 브리드화 하여 경로 추적한 것을 지도상에 나타낸다. 앱을 구현하기 위하여 에디터, 안드로이드 SDK,

안드로이드 개발 툴(ADT), 이클립스 등을 이용하 였고 지도는 국내 이용자에 친숙하고 다양한 기능을 오픈 API 형태로 제공하고 있는 Google Maps API를 활용하였다.

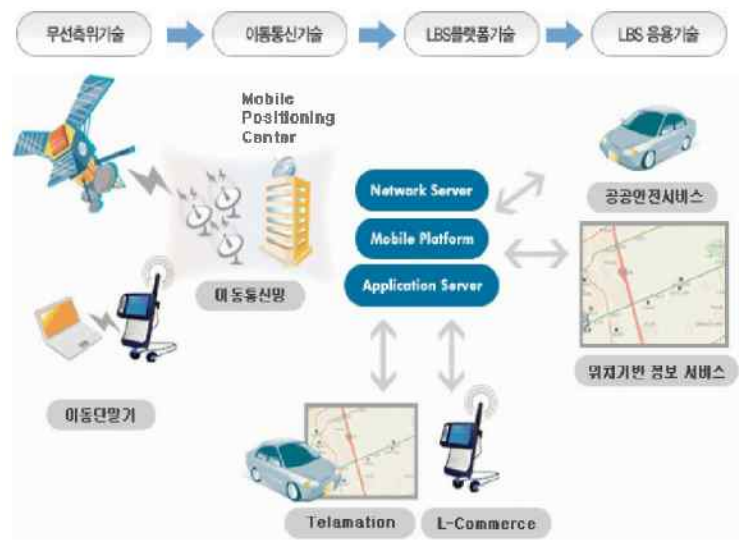

그림 2. 시스템 구성도

Fig. 2. System Configuration
3-2 거리계산

경로 추적 중 지도에 마커를 표시하기 위해서는시 간을 사용하거나 거리를 사용할 수 있는데 본 시스템 은 현 위치와 마지막 마커와의 거리를 이용하였다. 마커와의 거리가 짧으면 지도에 너무 촘촘하게 마커 가 나타나고 길면 이동한 경로가 많이 누락되므로 본 연구에서는 현 위치와 최종 마커와의 거리가 $20 \mathrm{~m}$ 이 상이면 지도에 새 마커를 표시하고 현 위치를 새로운 최종 마커의 위치로 갱신하도록 하였다. 거리 계산 은 최종 마커로 표시한 위치의 경도, 위도값을 (lon1, lat1), 현 위치의 경도, 위도값을 (lon2, lat2)로 할 때 구면에서의 두 좌표의 거리 $\mathrm{d}$ 는 식 1 과 같이 구면 코사인 법칙을 사용하여 계산하였다.

$$
\begin{aligned}
& \Delta \text { lon }=\operatorname{lon} 2-\operatorname{lon} 1 \\
& \Delta \text { lat }=\text { lat } 2-\operatorname{lat} 1 \\
& a=\sin ^{2}(\Delta \operatorname{lat} / 2)^{2}+ \\
& \cos (\text { lat } 1) \times \cos (\text { lat } 2) \times \sin ^{2}(\Delta \operatorname{lon} / 2) \\
& c=2 \times \tan ^{-1}\left(\frac{\sqrt{a}}{\sqrt{1-a}}\right) \\
& d=R \times c(\text { 여기서 } \mathrm{R} \text { 은 지구의 반지름) }
\end{aligned}
$$

3-3 시스템 기능

본 시스템은 "경로 추적 시작", "마커표시”, "중지” "경로추적 지도보기" 와 "경로추적 위성사진 보기" 의 다섯 가지 주 기능을 가지고 있다.

"경로 추적 시작" 기능은 GPS나 기지국을 이용하 여 현재 위치의 위도와 경도를 알아 지도에 경로 추 적의 처음 마커를 표시하며 초기 화면에서 “추적”버 튼을 눌러 시작한다.

“마커 표시”기능은 경로 추적을 위하여 지도에 마 커를 표시하는 기능이다. 3-2절에서 제안한 마커 사 이의 거리를 계산하여 이동경로를 계속 추적하여최 종 마커와의 거리가 $20 \mathrm{~m}$ 이상이면 시스템이 자동적 으로 새로운 마커를 표시한다.

"정지" 기능은 경로 추적을 종료하고 지금까지 마 커로 표시한 것을 지도상에 나타낸다.

"경로추적 지도보기" 기능과 "경로추적 위성사진 보기" 기능은 현재 위치를 중심으로 경로 추적한 결 과를 지도와 위성사진을 보여주며 확대, 축소와 이 


\section{추적 중지}

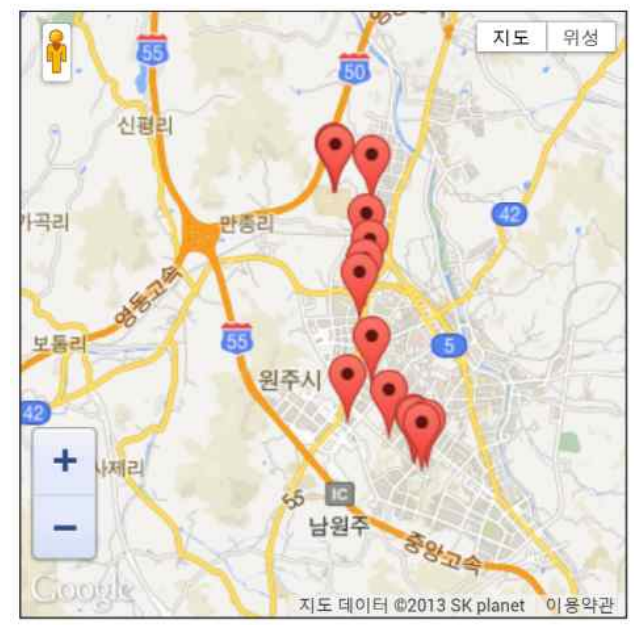

그림 3. 실행된 애플리케이션(지도)

Fig. 3. Executed Application(a map)

동 기능이 있다. 그림3과 그림4는 실제 모바일 기기 에서 실행된 화면이다.

\section{IV. 결 론}

본 논문에서는 LBS 기술을 이용하여 GPS 수신기 등 위치 정보 획득이 가능한 장치가 설치된 모바일 기기에서 경로 탐색 대상자나 사물의 위치정보를 확 인하고 경로추적을 할 수 있는 경로 추적 시스템을 설계 구현하였다.

본 논문에서 구현한 앱은 하이브리드 앱의 기본적 인 특징인 모든 모바일 기기의 플랫폼에서 실행할 수 있으며, 변경되는 지도 정보를 재배포할 필요없이 앱 에 실시간으로 적용할 수 있다. 또한 기존의 네이티 브 언어로 개발하는 것에 비하여 개발 시간 및 소스 코드 양의 절감효과가 있으며, 빠르고 손쉽게 사용자 인터페이스 설계를 할 수 있었다.

이 시스템을 이용하여 경로탐색이 필요한 여러 분 야, 예를 들어 어린 자녀나 치매 환자의 이동 경로 확 인, 범죄자의 이동 경로 추적, 그리고 차량, 항공기 등 수송기관의 내비게이션 앱 등을 모바일 기기에 관 계없이 빠르게 개발하는 것이 가능하게 되었다.

\section{추적 중지}

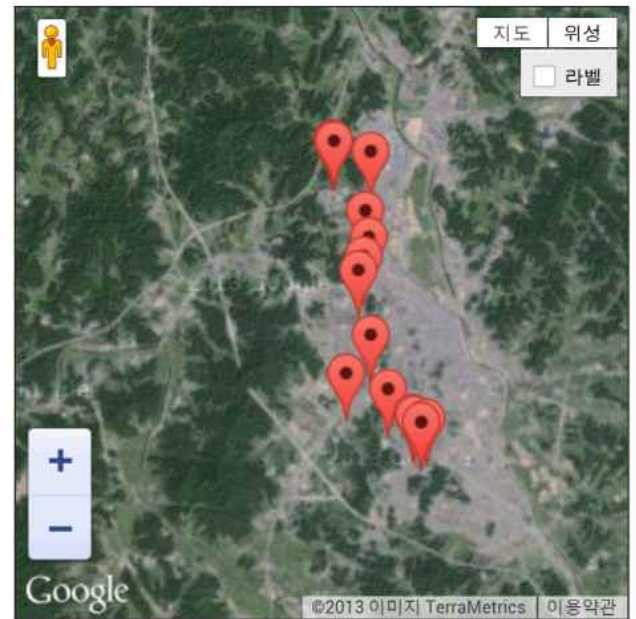

그림 4. 실행된 애플리케이션(위성사진)

Fig. 4. Executed Application (a satellite photo)

[1] Y. Shin, et al, Recent Trends of LBS. Information and Communications Magazine, vol. 28, no. 7, 2011

[2] C. Noe, K. Ki, Development of Monitoring Service based on Ubiquitous System, Proceedings of KAIS, 2009

[3] J. Chun, The Standards and Future of Next Generation Web, TTA Journal, vol. 128, 2010

[4] HTML5(2013), HTML5, A vocabulary and associated APIs for HTML and XHTML, http://www.w3.org/TR/htm151/

[5] W. Jung, J. Oh, and D. Yoon, Design and Implementation of Hybrid Mobile App Framework, KIICE Journal, vol. 16, no. 19, 2012

[6] K. Do, Y. Kim, D. Kim, and C. Kim, Application Design Using Hybrid App in Mobile Environment, Proceedings of KIIT, 2013

\section{유 문 성 (Moon-Sung Yoo)}

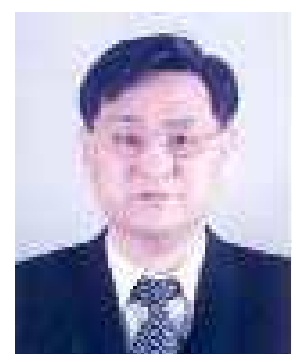

1978년 2월 : 서울대학교 수학과 (이학사) 1996년 12월 : 미국 루이지애나 대학교 컴퓨터공학과(공학박사) 2000년 9월 현재 : 상지대학교 컴퓨터공학부 교수 관심분야 : 모바일 웹 개발, 유비쿼터스 시스템, 소프트웨어공학

\section{Reference}

